\title{
Iatrogenic Female Genital Fistula, 35 Cases Report
}

\author{
N. Idi' ${ }^{1}$, I. Abdoulaye ${ }^{2}$, F. Chaibou Nomao' ${ }^{1}$, Z. Assoumane ${ }^{3}$ \\ ${ }^{1}$ Univerité A Moumouni, Niamey, Niger \\ ${ }^{2}$ CNRFO, Niamey, Niger \\ ${ }^{3}$ UNFPA, Niamey, Niger \\ Email: Idinafi@yahoo.fr
}

How to cite this paper: Idi, N., Abdoulaye, I.., Chaibou Nomao, F. and Assoumane, Z. (2020) Iatrogenic Female Genital Fistula, 35 Cases Report. Open Journal of Obstetrics and Gynecology, 10, 1156-1162. https://doi.org/10.4236/ojog.2020.1090109

Received: July 1, 2020

Accepted: August 31, 2020

Published: Sepetmber 3, 2020

Copyright $\odot 2020$ by author(s) and Scientific Research Publishing Inc. This work is licensed under the Creative Commons Attribution International License (CC BY 4.0).

http://creativecommons.org/licenses/by/4.0/ (c) (i) Open Access

\begin{abstract}
Introduction: Female genital fistula (FGF), remains a world concern, especially in low developed country. Obstructive (blocked) delivery labor is his principal cause, sometimes by pelvic surgery (urogenital or obstetrical, rectal) more rarely by congenital urogenital malformation, excision, pelvic neoplasm, pelvic radiotherapy. We were interested in iatrogenic FGF treated in the special referral fistula center. Methodology: We report 35 cases of iatrogenic female genital fistula. Are included only cases by urogenital surgery, excision in the National Referal Center of Obstetrical Fistula. Were not included cases happened by over 12 hours blocked delivery labor, caustic destruction, pelvic cancer pelvic infection and those with incomplete file. The epidemiologic, clinical and therapeutic information were studied. All ethical protocols were respected. Results: CNRFO recorded 743 cases of female genital fistula from May 232013 to May 23 May 2018 within 35 iatrogenic cases (4.71\%). Patients were 19 - 29 years old (42.85\%), average age 35 years old, extremes 19 - 60 years, without occupation (82.86), grand multiparous $48.57 \%$, with a mean of 4 previous deliveries. The principal constancies were hysterectomies $71.43 \%$, caesarean section $17.14 \%$, genital excision $11.42 \%$, and cystocele cure $11.42 \%$. The anatomical finds were soft vagina tissue $97.14 \%$ uretero-vaginal fistula $45.71 \%$ ( 2 cases post Caesarean, 14 cases post hysterectomy), vesico-vaginal 31.43\% (all post hysterectomy), ureteral 11.42\% (all post caesarean), 1 vesico-uterine $5.71 \%$ (case post caesarean), 1 case after a cystocele cure, 2 uretro-vaginal $11.42 \%$ secondary of genital excision. Treatment was ureteral reimplantation (18/31) cases by abdominal way, fistulorraphy (12/31) and luretroplasty by vaginal, 4 cases treated with transurethral bladder probe. 30 were cured by fistulas surgery, 1 urinary tress incontinency and 1 not closed, and 4 of transurethral bladder probe were cured. Conclusion: The female genital fistula is sometimes the consequence of Caesarean, hysterectomy, gynecological surgery, urologic surgery and some traditional practices.
\end{abstract}




\section{Keywords}

Female Genital Fistula, Iatrogenic Fistula, Excision, Pelvic Surgery, Caesarian, Hysterectomy

\section{Introduction}

Few morbidities give pain and discomfort to women as genital fistula. Obstetrical origin (dystocia blocked delivery labor) is most frequent. It can be by other circumstances as pelvic cancer, congenital, trauma accident and rarely urogenital infections.

The iatrogenic fistula results from pelvic surgery (urology, obstetric gynecology, rectum). It can happen also by instrumental manipulations on the pelvic organs [1]-[22], or negative traditional practice like excision (clitoris and or vular lips ablation). They are rare in developed countries [15] [16] [17]. Its prevalence worldwide ranges from $6 \%$ to $24 \%$ [1] [8].

Fistulas is still a public health problem in in-coming countries. Data from the literature on iatrogenic fistulas are still poor. So we were interested in this pathology for the circumstances and prognosis. The study was carried at the National Reference Center for Obstetric Fistulas (CNRFO) in Niamey. This is a retrospective descriptive study (over 5 years) (23/5/2013 -22/5/2018) on iatrogenic female genital fistulas.

\subsection{Inclusion Criteria}

Any female genital fistula noted following gynecological or urological surgery and or traditional practices on the female genital tract (excision), hospitalised in CNRFO during the period concerned and for which the file is usable.

\subsection{Non-Inclusion Criteria}

Any case of female genital fistula occurring during a cesarean section for dystocia blocked labor of more than 12 hours (117 cases), case associated with invasive pelvic cancer ( 1 case), accidental injury ( 0 case) by caustic products ( 0 case) or pelvic irradiation ( 0 case) and any case of incomplete file ( 2 cases).

\subsection{Collection of Data}

We collected continuous data at CNRFO for a period of three weeks on the basis of a pre-established survey form and hospital records during the study period.

All ethics procedures were respected.

\section{Results}

We recorded 743 cases of genital female fistula at CNRFO, including 35 cases of iatrogenic origin (4.71\%) (Table 1).

The average age was 35 years old, extremes 19 and 62 years old, $57.15 \%$ of the 
patients were over 30 years old. In $80 \%$ of cases, patients had at least 2 previous parities.

Table 1. Patients age years old.

\begin{tabular}{ccc}
\hline Age & Number & $\%$ \\
\hline $19-29$ & 15 & 42.85 \\
$30-39$ & 5 & 14.29 \\
$40-49$ & 10 & 28.57 \\
$>50$ & 5 & 14.29 \\
Total & 35 & 100 \\
\hline
\end{tabular}

The main circumstances were obstetrical (54.28\%) mainly the hemostasis (Table 2).

Table 2. Distribution of circumstances of the FGF.

\begin{tabular}{|c|c|c|c|c|}
\hline \multicolumn{3}{|l|}{ Obstetrical } & Number & $\%$ \\
\hline & \multicolumn{2}{|c|}{ Caesarian section } & 6 & 17.14 \\
\hline & \multicolumn{2}{|c|}{ hysterectomy for uterin rupture } & 4 & 11.43 \\
\hline & \multicolumn{2}{|c|}{ Hemostasis hysterectomy } & 9 & 25.72 \\
\hline & & Fibroid & 9 & 25.72 \\
\hline \multirow[t]{4}{*}{ Gynecological } & hysterectomy & Cervical cancer & 2 & 5.71 \\
\hline & & Prolapsus & 1 & 2.86 \\
\hline & \multicolumn{2}{|c|}{ excision } & 2 & 5.71 \\
\hline & \multicolumn{2}{|c|}{ Cystocele cure. } & 2 & 5.71 \\
\hline Total & & & 35 & 100 \\
\hline
\end{tabular}

Hysterectomy was the main circumstance of uretero-vaginal and vesico-vaginal fistulas, while traditional harmful practice (excision), was responsible for uretro-vaginal fistula (Table 3 ).

Table 3. Circumstance of FGF.

\begin{tabular}{ccccccc}
\hline FGF Type & Circumstance & Hysterectomy Caesarian & $\begin{array}{c}\text { Cystocele } \\
\text { cure }\end{array}$ & Excision & Total & $\%$ \\
\hline uretero-vaginal & 2 & 14 & 0 & 0 & 16 & 45.71 \\
vesico-vaginal & 0 & 9 & 2 & 0 & 11 & 31.43 \\
ureteral & 4 & 0 & & 0 & 4 & 11.43 \\
uretro-vaginal & 0 & 2 & 0 & 2 & 4 & 11.43 \\
Total & 6 & 25 & 2 & 2 & 35 & 100 \\
\hline
\end{tabular}

Distribution according to the type of treatment (Table 4): 
Table 4. Surgical treatment.

\begin{tabular}{ccc}
\hline Treatment & Number & $\%$ \\
\hline Fistulorraphy & 12 & 34.29 \\
Ureteral Reimplantation & $\mathbf{1 8}$ & $\mathbf{5 1 . 4 3}$ \\
Uretroplasty & 1 & 2.85 \\
Total & 31 & 88.57 \\
\hline
\end{tabular}

The treatment results after 3 months follow-up noted fistula closed and $29 \mathrm{pa}-$ tients dry $(82.87 \%), 1$ case $(2.85 \%)$ closed with stress incontinency and 1 case (2.85\%) non closed fistula. 4 patients treated by transurethral bladder probe were dry.

Fistula was closed and urinary continency in 30 cases (85.72\%). 4 cases (11.43\%) all cured with transurethral bladder probe treatment. The average length of hospital stay was 20 days (extremes 14 - 30 days), $20 \pm 7$ days.

\section{Discussion/Comment}

\subsection{Epidemiology}

During five years, CNRFO $4.71 \%$ of all female genital fistulas hosptalised, were iatrogenic. The age group most concerned was 19 - 29 years old, less 40 years old represented $57.15 \%$, average age 35 years old, extremes 19 - 62 years old, as in the previous study, Niger, 2018 [7] the age group of $20-29$ years was the most concerned. Although age old is not a risk factor of iatrogenic genital fistulas [1]-[9], it is important to mention in our study patients were young, $57.14 \%$ less 40 years old. The patients had 4 parities average, extremes 0 - 10 including large multiparous (37.14\%) (37.14\%), primiparous (11.43\%), Idi [7] Niger, 2018 finds $47.32 \%$ of primiparous, $39.85 \%$ multiparous. while Kazadi [13] reports 3 parity average.

\subsection{Circumstances of Lesion}

The most frequent causes were obstetrical surgery (54.28\%): including 6 cesarean sections (17.14\%), 4 hysterectomies for uterine rupture (11.43\%) and 9 hemostasis hysterectomies (25.71\%). Then gynecological causes (40\%) including: 9 hysterectomies (25.71\%) for fibroid, 2 hysterectomies for stage B2 cervix cancer (5.71\%) 1 hysterectomy for genital prolapsed $(2.86 \%), 2$ of genital excision (5.71\%) and 2 cystocele cures. In this study, hysterectomy was the main occasion for iatrogenic fistulas (71.43\%) then cesarean section (17.14\%). Farih [12] in Morocco, 2018 for 18 cases vaginal vesico-fistula, 12 cases were post-surgical ( 7 hysterectomies and 5 cesarean sections Odezebe at the Brazzavaville University Hospital [19] reported 11 cases (32.35\%) of post-cesarean fistulas and 6 cases (17.64\%) of post hysterectomy fistulas in a series of 34 urogenital fistulas.

For Onsrud [10], the Democratic Republic of Congo on 229 cesarean, 55 fistulas $(24 \%)$ were considered as iatrogens. Nawaz [11] in a retrospective study covering 13 years recorded 213 cases of urogenital fistulas of which 25 cases 
(18.79\%) were post hysterectomy and 9 (6.77\%) were post cesarean. In Goktas study [16], $71.5 \%$ of fistula were surgical complication.

\subsection{Anatomopathological Findings}

Farih [19] Morocco 2018 reported 12 cases of post-surgical vesico-vaginal fistula ( 3 by hysterectomy for uterine rupture, 1 hemostasis hysterectomy, 3 cases of hysterectomy for fibroid, 3 cases cesarean section for fetal distress and 2 cases of cesarean section for fetal-pelvic disproportion). El Tabey [13] in 18-years experience observed for 120 fistulas, 90 were vesico-vaginal, 14 uretro-vaginal, 2 vesico-uterines and one uretero-uterine, 13 ureteral ligations. Nawaz [11], in a retrospective study covering 13 years recorded 213 cases of urogenital fistulas, of which 133 (62.44\%) vesico-vaginal, 54 (25.35\%) uretero-vaginal and $26(12.2 \%)$ uretero-vaginal. The circumstances of occurrence were hysterectomy and cesarean section. El Lamine I [14] reports a retrospective series of 46 cases of urogenital fistulas collected in 7 years among which $2 \%$ were of iatrogenic cause, they were vesico-vaginal (48\%), unilateral uretero-vaginal (30\%), bilateral (13\%) and vesico-uterine (9\%). The iatrogenic causes were gynecological (57\%) and obstetrical (41\%). Goktas [16] reports 42 cases of uro-genital fistulas collected from May 2001 to June 2010: 28 vesico-vaginal fistulas, 11 vaginal uretro and 3 vesico-uterine fistulas. These fistulas were consecutive to surgery $(71.5 \%)$ and to obstetric trauma $(28.5 \%)$. In lot of publications vesico-uterine fistula as a rare complication of cesarean section, estimated $1 \%-4 \%$ of all urogenital fistulas [1]-[20].

\subsection{Treatment}

Upper fistula is treated by abdominal way [1] [2] [14] [15] [21] [22] [23]. The vaginal way is indicated for uretro-vaginal and vesico-vaginal fistula. The goal was to restore as possible, the anatomical and functional integrity of the urinary and genital tractus. Thus 18 fistulas (14 uretero-vaginal and 4 ureteral were repaired by ureteral reimplantation according to Leadbetter-Politano technique which is the most commonly used. It can be used even for higher lesions of the ureter [22] [24]. The fistulorraphy concerned 12 fistulas (9 vesico-vaginal, 2 vesico-uterine and one uretero-vaginal). One case of urethroplasty was reported. Manconi [24] reports 3 cases of terminal terminus anastomosis, 2 cases of ureteral reimplantation and a psoic bladder. Modi [23] reported 18 cases of vaginal uretro fistulas collected between 2003 and 2007 following hysterectomy, the treatment was by laparoscopic ureteral reimplantation and Posoas hitch.

\subsection{Prognosis}

The treatment results after 3 months follow-up noted fistula closed and patient dry in 29 cases $(82.87 \%), 1$ case $(2.85 \%)$ closed with stress incontinency and 1 case $(2.85 \%)$ non-closed fistula. 4 patients treated by trans urethral bladder probe were dry (11.43\%). For Bouya et al. [25], there were 20 cases of healing 
$76.92 \%), 3$ cases of failure (11.53\%), 3 cases with persistence of urinary incontinence despite the anatomical closure of the fistula.

\section{Conclusion}

Female genital fistula is a morbidity but not vital danger. It is a big public health problem in Niger country. Our study concerns 35 cases of iatrogenic fistulas in 5 years treated at the CNRFO in Niamey. They are pelvic surgery complications (obstetric, gynecological, urological surgery) and genital mutilation of urogenital tract (excision). The better knowledge of urogenital/female anatomy relative modification may improve pelvic surgery. The surgical techniques and active action against traditional genital mutilation can avoid iatrogenic genital fistula. The treatment result is almost excellent when done by trained and skilled surgeons. The small vesico-vaginal could be closed by transvaginal bladder probe.

\section{Conflicts of Interest}

The authors declare no conflicts of interest regarding the publication of this paper.

\section{References}

[1] Raossen, T.J.I.P., Ngongo, C.J. and Mahendeka, M.M. (2014) Iatrogenic Genitourinary Fistula: An 18-Year Retrospective Review of 805 Injuries. International Urogynecology Journal, 25, 1699-1706.

[2] Obarisiagbon, E.O., Olagbuj, B.N., Omora, V.C., Oguike, T.C. and Ande, A.B.A. (2011) Iatrogenic Urological Injuries Complicating Obstetric and Gynecological Procedure. Singapore Medical Journal, 52, 738-741.

[3] Benchekroun, A., El Alj, H.A., El Sayegh, H., et al. (2003) Les fistules vesico-vaginale: À propos de 1050 cas. Annale D’ urologie, 37, 194-198. https://doi.org/10.1016/S0003-4401(03)00053-6

[4] Labarrère, A., Gueye, A., Ouaki, F., et al. (2011) Fistule urogénitale obstétricale: A propos de deux fistules uretèro vaginale. Alternative thérapeutique à propos de 10 cas. Observation en France. Gynécologie Obstétrique \& Fertilité, 39, 328-331.

[5] Anou Kouma, T., Attipoub, K.K., Agoda-Koussemac, L.K., et al. (2010) Aspect épidémiologique, étiologique et thérapeutique de la fistule obstétricale au Togo. Progrès en Urologie, 20, 71-76. https://doi.org/10.1016/j.purol.2009.08.038

[6] Gwyneth, L. and de Bernis, L. (2009) Principes directeur pour la prise en charge clinique et le développement des programmes. Organisation Mondiale de la Santé (OMS).

[7] Idi, N., Brah, N.A.H.M., Idrissa, A., Djangnikpo, L. and Assoumana, Z. (2018) Multicentric Study of 148 New Cases of Female Genital Fistula Niger. Open Journal of Obstetrics and Gynecology, 8, 1631-1639. https://doi.org/10.4236/ojog.2018.814162

[8] Duncan, J.S., Noam, D.K., Nico Laos, L., et al. (2012) Cuideline ou Iatrogene Trauma. European Urology, 62, 628-639. https://doi.org/10.1016/j.eururo.2012.05.058

[9] Kazadi, J.B. and Ndione, J.B. (2001) Syndrome de Youssef ou fistule vesico-utérine après césarienne, analyse rétrospective de 6 dossiers. Médecine d Afrique Noire, 48, 274-279. 
[10] Onsrud, M., Sjoveean, S. and Mukwege, D. (2011) Cesarean Delivery Related Fistula in the Democratic Republic of Congo. International Journal of Gynecology \& $\mathrm{Ob}$ stetrics, 114, 10-14. https://doi.org/10.1016/j.ijgo.2011.01.018

[11] Nawaz, H., Khan, M., Tareen, F.M., et al. (2010) Retrospective Study of 213 Cases of Female Urogenital Fistulae at the Department of Urology \& Transplantation Civil Hospital Quetta, Pakistan. Journal of Pakistan Medical Association, 60, 28-32.

[12] Farih, M.H., Tazi, M.F., El Mohamed, J.E. and Mellas, S. (2018) Fistule vesico vaginale à propos de 18 cas, étude descriptive et analytique, service d'urologie $\mathrm{CHU}$ Hassan II de Fès Maroc. Thèse de Médecine.

[13] El Tabey, N.A., Ali El Dein, B., Shaaban, A.A., El Kappany, H.A., Mokhtar, A.A., El Azab, M., et al. (2006) Urological Trauma after Gynecological and Obstetric Surgeries, Experience with These Injuries over the Last 18 Years. Scandinavian Journal of Urology and Nephrology, 40, 225-231. https://doi.org/10.1080/00365590600589476

[14] El-Lamine, I.K. (2008) Urogenital Fistulae: Changing Trends and Personal Experience of 46 Cases. International Urogynecology Journal and Pelvic Floor Dysfunction, 19, 267-272. https://doi.org/10.1007/s00192-007-0426-5

[15] Nafiou, I., Djangnikpo, L., Sani, R., Harouna, S. and Chekaraou, L. (2017) Fistules génitales féminines d'origine obstétricale. Etude multicentrique prospective a propos de 148 nouveaux cas. Niger OJOG 2018, 8.

[16] Goktas, C., Horuz, R., Faydaci, G., et al. (2011) Treatment of Urogenital Fistula in Women. Actas Urológicas Españolas, 36, 196-197.

[17] Drissi, M., Karmouni, T., Tazi, K., El Khader, K., Koutuni, A., et al. (2008) Vesico Uterine Fistulas: Ban Experience of 17 Year. Progrès en Urologie, 18, 173-176. https://doi.org/10.1016/j.purol.2007.12.011

[18] Waheed, N., Hanif, M. and Chaudhri, R. (2010) Post-Cesarean Vesicouterine Fistula (Youssef's Syndrome). Rawal Medical Journal, 35, 111-112.

[19] Odezebe, H.W.S., Bouya, P.A. and Ele, N. (2011) Les fistules urogenital aspect ethiopathogenic et thérapeutique au CHU de Brazaville. Mali Médical, 26, 5-7.

[20] Kidmas, A.T. and Obekpa, P.O. (2005) Vesico-Uterine Fistula. Tropical Doctor, 35, 123-124. https://doi.org/10.1258/0049475054037138

[21] Michel, S. and Baggish, M.D. (2010) Urinary Tract Injuries Secondary to Gynecologic Laparoscopic Surgery: Analysis of 75 Case. Journal of Gynecologic Surgery, 26, 79-92. https://doi.org/10.1089/gyn.2010.0019

[22] Culty, T., Lebret, T. and Botto, H. (2018) Lésion opératoire de l'uretère. ECM (Elsevier Masson SAS, Paris). Urologie, 18-160-A-10.

[23] Modi, P., Gupta, R. and Rizvi, S.J. (2008) Laparoscopic Ureteroneocystostomy and Psoas Hitch for Post Hysterectomy, Ureterovaginal Fistula. The Journal of Urology, 180, 615. https://doi.org/10.1016/j.juro.2008.04.029

[24] Manconi, A.M. (2002) The Hygencologic Ureter Visited. Archivio Italiano di Urologia e Andrologia, 74, 23-24.

[25] Bouya, P.A., Nganongo, W.I., Lamine, D., et al. (2002) éTude rétrospective de 34 fistules urogénitales d'origine obstétricale. Gynécologie obstétrique et fertilité, 30, 780-783. 